\title{
EFFECT OF BIOSTIMULANT AND MICRONUTRIENT ON EMERGENCE, GROWTH AND QUALITY OF ARABICA COFFEE SEEDLINGS
}

\author{
Bruno Costa Ferreira ${ }^{1}$, Sebastiao Ferreira de Lima², Cátia Aparecida Simon ${ }^{3}$, \\ Maria Gabriela de Oliveira Andrade ${ }^{4}$, Jorgiani de Ávila ${ }^{5}$, Rita de Cássia Félix Alvarez ${ }^{6}$
}

(Received: March 08, 2018; accepted: April 20,2018)

\begin{abstract}
The micronutrients and biostimulant use can promote root, shoot and seedling growth. The aim of this work was evaluated the micronutrients and biostimulant application effects on arabica coffee seedling development. The experimental design was a randomized block in factorial 5 x 3, with four replicates. Five cultivars of arabica coffee (Topázio, Catuaí Amarelo, Catuaí Vermelho 99, Catuaí Vermelho 144 and Catiguá) cultivated in green house, combined with biostimulant (Stimulate ${ }^{\circledR}$ ), of micronutrients $(\mathrm{Mo}+\mathrm{Co})$ and control. 150 days after sowing the plants was evaluated. The higher seed germination velocity (0.10) was obtained with micronutrients and biostimulant. The higher height of plant, $8.88 \mathrm{~cm}$, was attained with biostimulant on Catuaí Amarelo. Catuaí Amarelo and Vermelho obtained higher number of leaves (4.5) with biostimulant use and the Catuaí Amarelo (4.38) with micronutrients use. In Catuaí Amarelo was attained higher shoot dry mass and leaf area with biostimulant use, reach $1.69 \mathrm{~g}$ and $19.55 \mathrm{~cm}^{2}$, respectively. The higher root dry mass values $(0.76 \mathrm{~g})$ and Dickson quality index $(0.47$ and 0.48 ) was attained with micronutrients use to the Catuaí Amarelo e vermelho cultivars. Seedling development of Catuaí Amarelo was benefited with Stimulate ${ }^{\circledR}$ application and the cultivar Topázio did not get positive development with Stimulate ${ }^{\circledR}$ and micronutrients application.
\end{abstract}

Index terms: Coffea arabica ., Stimulate ${ }^{\circledR}$, molybdenum + cobalt, Dickson quality index.

\section{EFEITO DE BIOESTIMULANTE E MICRONUTRIENTE NA EMERGÊNCIA, CRESCIMENTO E QUALIDADE DE MUDAS DE CAFÉ ARÁBICA}

RESUMO: O uso de bioestimulante e micronutriente pode promover o crescimento de raízes e parte aérea de mudas de plantas. Assim, o objetivo do trabalho foi avaliar o efeito da aplicação de bioestimulante e micronutriente no desenvolvimento de mudas de café arábica. O delineamento experimental foi em blocos ao acaso, em esquema fatorial 5 x 3, com quatro repetições. Foi utilizado cinco cultivares de café arábica (Topázio, Catuaí Amarelo, Catuaí Vermelho 99, Catuaí Vermelho 144 e Catiguá) cultivadas em casa de vegetação, associado a aplicação do bioestimulante (Stimulate $\left.{ }^{\circledR}\right)$, de micronutriente $(\mathrm{Mo}+\mathrm{Co})$ e controle. As plantas foram avaliadas 150 dias após a semeadura. O maior índice de velocidade de germinação de sementes $(0,10)$ foi obtido com bioestimulante e com micronutriente. A maior altura de planta, $8,88 \mathrm{~cm}$, foi atingida com o bioestimulante em Catuaí Amarelo. O Catuaí Amarelo e o Catuaí Vermelho obtiveram maior número de pares de folhas $(4,5)$ com uso de bioestimulante e o Catuaí Amarelo $(4,38)$ com uso de micronutriente. Em Catuaí Amarelo foram atingidos maiores massa seca da parte aérea e área foliar com uso do bioestimulante, chegando a $1,69 \mathrm{~g}$ e $19,55 \mathrm{~cm}^{2}$, respectivamente. Os maiores valores de massa seca de raiz $(0,76 \mathrm{~g})$ e índice de qualidade de Dickson $(0,47$ e 0,48$)$ foram obtidos com o uso de micronutrientes para as cultivares de Catuaí Amarelo e vermelho. O desenvolvimento de mudas de Catuaí Amarelo foi beneficiado com a aplicação de Stimulate ${ }^{\circledR}$ e a cultivar Topázio não obteve desenvolvimento positivo quando aplicado o Stimulate ${ }^{\circledR}$ e o micronutriente.

Termos de indexação: Coffea arabica, Stimulate ${ }^{\circledR}$, molibdênio + cobalto, índice de qualidade de Dickson.

\section{INTRODUCTION}

Brazil has 2.21 million hectares planted with coffee, in which $81 \%$ corresponds to crops planted with arabica coffee (Coffea arabica L.), despite the decrease in area planted with coffee in recent years, the country stands out as the leader in exports of this species. Nevertheless, studies show that there was a gain in productivity due to the use of new technologies in the production of vigorous seedlings, new varieties, adequate fertilization, irrigation, among other types of cultural treatments (Companhia Nacional de Abastecimento - CONAB, 2017).

A good performance in the development of coffee seedlings can be achieved by the application of biostimulants and micronutrients, which can enhance nutrient uptake by plants (BINSFELD et al., 2014), in which the biostimulant is characterized as being a natural substance or synthetic, produced from plant regulators such as

1,2,5,6Universidade Federal de Mato Grosso do Sul/ UFMS - Campus Chapadão do Sul/CPCS - Departamento de Agronomia - Cx. P. 112 - 79. 570-000 - Chapadão do Sul - MS - brunoferreira.agro@gmail.com, sebastiao.lima@ufms.br, jorgianiavila@hotmail.com, rita.alvarez@ufms.br

${ }^{3}$ Escola Superior de Agricultura Luiz de Queiroz/ ESALQ - Universidade de São Paulo / USP - Departamento de Ciências do Solo - 13.416-145 - Piracicaba - SP - catiasimon@usp.br

${ }^{4}$ Universidade Estadual Paulista/UNESP-Campus Itha Solteira - 15385-000 - Ilha Solteira - SP- gabriela13andrade@ hotmail.com

Coffee Science, Lavras, v. 13, n. 3, p. 324 - 332, jul./sep. 2018 
cytokinins, gibberellins and auxins, and can be mixed with other nutritional elements, thus acting on the cellular metabolism due to its natural or synthetic composition from regulators (SILVA et al., 2012; SILVA; TEODORO; MELO, 2008).

Micronutrients, as in this case, molybdenum and cobalt are of extreme physiological importance for plants, especially for the biological nitrogen fixation process in legumes (WEISANY; RAEI; ALLAHVERDIPOOR, 2013). Molybdenum, in turn, acts as a cofactor in the enzymatic complex of nitrate reductase for nitrogenase and sulfide oxidase, donating electrons, being one of the responsible for the nitrate assimilation in vegetables, this in turn, for being an anion has its availability in synergism with increasing $\mathrm{pH}$, and its deficiency in acid $\mathrm{pH}$, in coffee cultivation, molybdenum is required in a few quantities, about $3 \mathrm{mg}$ per bag of coffee (TAIZ et al., 2017; SFREDO; OLIVEIRA, 2010; MALAVOLTA, 2006). However, for cobalt, there are few reports of its importance in coffee cultivation, but it is known that this essential element has great importance for nitrogen-fixing plants, in which it acts in the synthesis processes of vitamin $\mathrm{B}_{12}$, cobamide and leghemoglobin in nitrogenfixing nodules (SFREDO; OLIVEIRA, 2010). Some authors describe that micronutrient seed treatment has the potential to meet cultural needs in relation to mineral nutrition and to improve plant emergence, yield and grain enrichment. In addition, Mo application in seed is more effective compared to application in the soil for many cultures (FAROOQ; WAHID; SIDDIQUE, 2012).

Nevertheless, in the Brazilian academic field, different studies have been carried out with the aim of promoting better coffee development and productivity, connected studies to identify molecular markers related to the coffee resistance $(C$. arabica) to rust (Hemileia vastatrix) (ALVARENGA et al., 2011), to the productive and economic performance of the arabica coffee consortium, under rainfed and drip irrigated conditions (PERDONÁ; SORATTO; ESPERANCINI, 2015; BONOMO et al., 2008) are examples of the broad approach of Brazilian coffee research, although there is much information on the cultivation of arabica coffee, few studies have described the influence of the addition of biostimulant and micronutrients on the seedlings production in nursery. Thus, it is necessary to use new technologies that promote good development of vigorous seedlings, which provide good survival, reduced replanting and fast initial plant growth (ALVES; GUIMARÃES, 2010).
The use of biostimulant in the production of seedlings of different species has been tested with diverse results. The application of biostimulant in seeds of Genipa americana L. increased the seed emergence velocity and root length (PRADO NETO et al., 2007), also increased seedling emergence in Dimorphandra mollis Benth. (CANESIN et al., 2012) and mass of dry matter and leaf area of Campomanesia adamantium (Cambess.) O.Berg, (SCALON et al., 2009). On the other hand, it did not result in the growth in height and diameter of Jacaranda decurrens Cham. (KISSMANN et al., 2011) and in high doses, inhibited the emergence and development of Hymenaea courbaril L. seedlings (PIERAZAN; SCALON; PEREIRA, 2012).

Due to the great economic potential provided by this crop in the country, this work had as objective to evaluate the effect of the application of biostimulants and micronutrients (molybdenum and cobalt) in the production of Arabica coffee seedlings.

\section{MATERIAL AND METHODS}

The work was carried out in a greenhouse, belonging to the Forest Engineering Department, from experimental area of the Federal University of Mato Grosso do Sul, Chapadão do Sul campus Chapadão do Sul-MS. The climate is classified by the Köppen method as tropical humid the annual temperature is from 13 to $29{ }^{\circ} \mathrm{C}$, the average rainfall is $1.850 \mathrm{~mm}$, with rainfall concentration in summer and winter dryness (CUNHA; MAGALHÃES; CASTRO, 2013).

The experimental design was a randomized complete block, in a $5 \times 3$ factorial scheme, with 4 replicates. The treatments resulted in the use of five arabica coffee varieties (Topázio, Catuaí Amarelo, Catuaí Vermelho 99, Catuaí Vermelho 144 and Catiguá) combined with the application of biostimulant ( $25 \mathrm{~mL} \mathrm{~L}^{-1}$ of water), micronutrient (25 mL L $\mathrm{mL}^{-1}$ of water) and in the absence of biostimulant and micronutrient (control), the seeds were immersed in solution for two hours. The plots were composed of polyethylene trays of 96 tubes with conical shape, capacity of $120 \mathrm{~mL}$.

The description of the biostimulant and the micronutrient was carried out according to the manufacturer's information. The biostimulant used was Stimulate ${ }^{\circledR}$, a liquid product composed of three plant regulators containing $90 \mathrm{mg} \mathrm{L}^{-1}$ $(0.009 \%)$ kinetin, $50 \mathrm{mg} \mathrm{L}^{-1}(0.005 \%)$ gibberellic acid, $50 \mathrm{mg} \mathrm{L}^{-1}(0.005 \% \%)$ of indolebutyric acid 
and $99.981 \%$ of inert ingredients. The Power Seed ${ }^{\circledR}$ is a liquid fertilizer, foliar application, composed of two micronutrients, with $12.50 \%$ Molybdenum and $1.25 \%$ Cobalt.

Coffee cultivars sowing was carried out in 96-cell trays, filled with a standard substrate, composed of $70 \%$ sifted soil and 30\% commercial Plantmax $^{\circledR}$ substrate. Three coffee seeds were placed in each cell at a depth of $2 \mathrm{~cm}$. After seedlings establishment that occurred 7 to 10 days after germination, thinning was performed leaving only one plant per cell. Germination occurred from 56 to 102 days after sowing. The evaluations were performed 150 days after sowing, in which the seedlings were removed from the trays, washed with tap water to remove the adherent substrate.

The evaluated parameters were: germination speed seed obtained by the formula: GSI $=\mathrm{G} 1$ / $\mathrm{N} 1+$ G2/N2 + .. Gn/Nn (MAGUIRE, 1962); seedling height $(\mathrm{cm})$ measured with millimeter ruler, from the collar to the apical bud; collar diameter, expressed in $\mathrm{mm}$, measured using a pachymeter with an accuracy $0.01 \mathrm{~mm}$; number of leaf pairs; leaf area $\left(\mathrm{cm}^{2}\right)$, estimated with leaf area meter LI-COR model LI-3000; shoot/root dry mass (grams) determined in a forced circulation oven at $75{ }^{\circ} \mathrm{C}$ until constant weight; Dickson quality index obtained by the formula $\mathrm{DQI}=$ [total dry mass/(HDR + SRDMR)] (DICKSON; LEAF; HOSNER, 1960); shoot height/collar diameter ratio (HDR); height/shoot dry mass ratio (HSDMR), shoot/root dry mass ratio (SRDMR); total dry mass (grams), obtained by the sum of dry mass from leaves, stem and root.

The obtained data were submitted to variance analysis $(\mathrm{p}<0.05)$, Tukey test was used, at a 5\% probability level, according to the Sisvar computational program (FERREIRA, 2008).

\section{RESULTS AND DISCUSSION}

There was a significant effect $(\mathrm{p}<0.05)$, by the $\mathrm{F}$ test in all evaluated parameters. For the germination speed index (GSI), the seeds from different arabica coffee cultivars submitted to biostimulant and micronutrient application obtained different responses when compared to the control (Table 1).

The comparison among the treatments by the Tukey test (5\%) indicates that the biostimulant presented better germination efficiency for the cultivars Catiguá, Catuaí Amarelo and Catuaí Vermelho 99 (Table 1). The highest total averages reached by the GSI were obtained for the Catuaí Amarelo cultivar, in the treatments with biostimulant and micronutrient, for these, there was no significant difference between them, indicating that when the biostimulant and the micronutrient were used the seedlings had better GSI. The results obtained for the germination speed index show different responses as to the type of cultivar within the treatments. The obtained results were similar to those obtained by Medina et al. (2016), in which there was greater stimulation of seed germination when the biostimulant FitoMas-E (obtained from a biochemical compound with high content of amino acids, nitrogenous bases, saccharides and polysaccharides potentially active, is used to increase and accelerate biochemical reactions, such as seed germination, root stimulation (ESQUIROL et al., 2016)) was applied in arabica coffee seeds.

The Catuaí Amarelo exhibited higher average values for plant height and number of leaf pairs per plant when compared to other cultivars. For plant height the highest average was obtained with the Catuaí Amarelo cultivar, and the Catuaí Vermelho 99 cultivar presented lower average for plant height and collar diameter, the biostimulant application provided higher plant height and number of leaf pairs for the Catuaí Amarelo variety (Table 2).

For the Topázio and Catuaí Vermelho 144 cultivars, the biostimulant use resulted in a lower plant height compared to the micronutrient and the control. The micronutrient application did not result in gains in height for coffee seedlings, but also did not affect the growth in height of the cultivars, unlike what was observed with the biostimulant in the Topázio and Catuai vermelho 99 cultivars (Table 2). According to Pierazan, Scalon and Pereira (2012), the combination of plant regulators, present in the biostimulant, can increase plant growth and development, stimulating cell division, differentiation and cell elongation.

More specifically, the gibberellic acid present in the biostimulants can influence in the seedlings elongation, acting in the stem and the leaves of the plants growth regulating the height (LAVAGNINI et al., 2014). Thus, we can infer that Catuaí Vermelho 99, Catiguá and Catuaí Amarelo cultivars were influenced by the Stimulate ${ }^{\circledR}$ composition, due to the gibberellin and cytokinin presence. The cytokinins act to promote the shoot growth, due to the increase of the cellular proliferation in the apical meristem of the stem (TAIZ et al., 2017); in addition, it can interact with other hormones, including gibberellin. 
TABLE 1 - Germination speed index from the first emerged seedling of arabica coffee cultivars submitted to biostimulant and micronutrient application, Chapadão do Sul - MS, 2015.

\begin{tabular}{cccccc}
\hline \multicolumn{5}{c}{ Cultivars } \\
\hline TRE & Topázio & Catuaí Vermelho 99 & Catiguá & Catuaí Amarelo & Catuaí Vermelho 144 \\
\hline CONT & $0.07 \mathrm{aB}$ & $0.07 \mathrm{aB}$ & Germination speed index \\
$\mathrm{BIO}$ & $0.06 \mathrm{bC}$ & $0.07 \mathrm{aB}$ & $0.07 \mathrm{cB}$ & $0.08 \mathrm{bA}$ & $0.06 \mathrm{bB}$ \\
$\mathrm{Co}+\mathrm{Mo}$ & $0.04 \mathrm{cC}$ & $0.03 \mathrm{bC}$ & $0.08 \mathrm{bB}$ & $0.10 \mathrm{aA}$ & $0.04 \mathrm{cD}$ \\
\hline $\mathrm{CV}(\%)=4.79$ & & DMS TRE $=0.007$ & DMS Cultivars $=0.006$
\end{tabular}

Averages followed by the same lowercase in the column and upper case in the line, do not indicate a significant difference between them by the Tukey test (5\%). TRE $=$ treatment; $\mathrm{CONT}=$ control; $\mathrm{BIO}=$ biostimulant; $\mathrm{Co}+\mathrm{Mo}$ $=$ cobalt + molybdenum; CV $(\%)=$ coefficient of variation; DMS = significant minimal difference.

TABLE 2 - Evaluation of plant height, collar diameter, number of leaf pairs at 196 days after sowing for different cultivars of arabica coffee submitted to biostimulant and micronutrient application, Chapadão do Sul - MS, 2015.

\begin{tabular}{|c|c|c|c|c|c|}
\hline \multicolumn{6}{|c|}{ Cultivars } \\
\hline & Topázio & Catuaí Vermelho 99 & Catiguá & Catuaí Amarelo & Catuaí Vermelho 144 \\
\hline TRE & \multicolumn{5}{|c|}{ Evaluation of plant height $(\mathrm{cm})$} \\
\hline CONT & $6.69 \mathrm{aC}$ & $5.66 \mathrm{aD}$ & $7.04 \mathrm{aBC}$ & $7.78 \mathrm{bA}$ & $7.20 \mathrm{aB}$ \\
\hline $\mathrm{BIO}$ & $5.90 \mathrm{bD}$ & $5.68 \mathrm{aD}$ & $7.15 \mathrm{aB}$ & $8.88 \mathrm{aA}$ & $6.73 \mathrm{bC}$ \\
\hline $\mathrm{Co}+\mathrm{Mo}$ & $6.35 \mathrm{aC}$ & $5.70 \mathrm{aD}$ & $7.05 \mathrm{aB}$ & $7.75 \mathrm{bA}$ & $7.40 \mathrm{aAB}$ \\
\hline \multicolumn{2}{|c|}{$\mathrm{CV}(\%)=2.94$} & \multicolumn{2}{|c|}{ DMS TRE $=0.41$} & \multicolumn{2}{|c|}{ DMS Cultivars $=0.35$} \\
\hline \multicolumn{6}{|c|}{ Collar diameter $(\mathrm{mm})$} \\
\hline CONT & $2.50 \mathrm{aAB}$ & $2.13 \mathrm{aC}$ & $2.46 \mathrm{aB}$ & $2.59 \mathrm{aA}$ & $2.55 \mathrm{aAB}$ \\
\hline $\mathrm{BIO}$ & $2.38 \mathrm{bA}$ & $2.14 \mathrm{aB}$ & $2.35 \mathrm{bA}$ & $2.23 \mathrm{bB}$ & $2.40 \mathrm{bA}$ \\
\hline $\mathrm{Co}+\mathrm{Mo}$ & $2.49 \mathrm{aB}$ & $2.11 \mathrm{aD}$ & $2.35 \mathrm{bC}$ & $2.63 \mathrm{aA}$ & $2.58 \mathrm{aAB}$ \\
\hline \multicolumn{2}{|c|}{$\mathrm{CV}(\%)=2.10$} & \multicolumn{2}{|c|}{ DMS TRE $=0.10$} & \multicolumn{2}{|c|}{ DMS Cultivars $=0.08$} \\
\hline \multicolumn{6}{|c|}{ Number of leaf pairs } \\
\hline CONT & $4.13 \mathrm{aB}$ & $4.25 \mathrm{aA}$ & $3.75 \mathrm{aB}$ & $4.13 \mathrm{bB}$ & $4.24 \mathrm{aB}$ \\
\hline $\mathrm{BIO}$ & $3.63 \mathrm{bC}$ & $4.13 \mathrm{bA}$ & $3.88 \mathrm{aB}$ & $4.25 \mathrm{abA}$ & $4.25 \mathrm{aA}$ \\
\hline $\mathrm{Co}+\mathrm{Mo}$ & $3.63 \mathrm{bD}$ & $3.63 \mathrm{cD}$ & $3.88 \mathrm{aC}$ & $4.38 \mathrm{aA}$ & $4.13 \mathrm{aB}$ \\
\hline
\end{tabular}

Averages followed by the same upper case in the line and lowercase in the column, do not differ each other by Tukey test $(5 \%)$. TRE $=$ treatment; $\mathrm{CONT}=$ control; $\mathrm{BIO}=$ biostimulant; $\mathrm{Co}+\mathrm{Mo}=$ cobalt + molybdenum; $\mathrm{CV}$ $(\%)=$ coefficient of variation; DMS = significant minimal difference.

The Catuaí Vermelho 144 cultivar had the highest collar diameter average, and the Catuaí Vermelho 99 variety was the one that presented the lowest average value within this parameter (Table 2). The different cultivars obtained very different responses to the stem increase both in the presence or absence of the products. It was observed that with the biostimulant application for Topázio, Catuaí Amarelo and Catuaí Vermelho 144 cultivars presented positive results, differing from the other cultivars. With the micronutrient application, the lowest stem diameter growth result was for the Catuaí Vermelho 99 cultivar, differing from the other cultivars. The micronutrient use did not statistically differ when compared to the control within the cultivars, except for the Catiguá cultivar. The cultivars that exhibited the best growth of stem diameter in the three treatments were Topázio, Catuaí Amarelo and Catuaí Vermelho 144. 
The biostimulant application damaged the leaves production of Topázio and Catuaí Vermelho 99 cultivars while the micronutrients use was harmful only to the Topázio cultivar (Table 2). The control statistically differed from the other treatments for Topázio cultivar, do not differ from the treatment with micronutrients within the Catuai Vermelho 99 cultivar. For the number of leaf pairs it is observed that only Catuaí Amarelo cultivar responded positively to the biostimulant treatment, do not differ from the $\mathrm{Mo}+\mathrm{Co}$ application. Corroborating with Medina et al. (2016), in which the FitoMas-E application also at dose 3.0 $\mathrm{ml}^{-1}$ in the seeds imbibition and a second foliar application after 150 days of sowing promoted a greater number of coffee leaf pairs. Tecchio et al. (2015), evaluating the effect of Stimulate ${ }^{\circledR}$ on the growth of Kunquat 'Nagami' seedlings applied at different concentrations $(0,50,100,150$ and 200 $\mathrm{mL} \mathrm{L}$ of solution), describe in their results that the dose of $200 \mathrm{~mL}$ L of Stimulate ${ }^{\circledR}$ promoted increase in plant height, number of leaves, root length and cup diameter of Kunquat 'Nagami' seedlings. For the treatment with biostimulant and micronutrient, the lowest average number of leaf pairs was observed in the Topázio cultivar, with a statistical difference among the others. The cultivars presented differentiated leaf pairs formation as a function of the products application.

Shoot, root and leaf area dry mass of arabica coffee cultivars obtained positive responses to the biostimulant and micronutrient application (Table 3).

The biostimulant application damaged the shoot dry mass production of Topázio and Catuaí Vermelho 144 cultivars, while the micronutrient was harmful to the Catuaí Vermelho 99 cultivar. The Catuaí Amarelo cultivar obtained the highest shoot dry mass, when compared to the other cultivars, both for the absence of products, and in the biostimulant and micronutrient presence (Table 3).

Regarding root dry mass, Catuaí Amarelo cultivar had a higher total averages value for root dry mass production, and the lowest root dry mass production occurred within the Catuaí Vermelho 99 cultivar. The biostimulant application provided the highest root growth for Catuaí Vermelho 99 cultivar, differing from the treatment with micronutrient and the control. The biostimulant application damaged the root growth for Catuaí Amarelo cultivar, differing from the other treatments (Table 3 ). It can be inferred that the presence of the cytokinin hormone had harmed the root development, because it acts on the cellular differentiation in the apical meristem, a contrary effect to that cytokinin and auxin, in which it promotes the cellular division of the apical meristem (TAIZ et al., 2017).

The micronutrient application in the Catiguá, Catuaí Amarelo and Catuaí Vermelho 144 cultivars presented a better root mass development, differing from the control for the Catiguá cultivation, and differing from the other treatments of Catuaí Amarelo and Catuaí Vermelho 144 cultivars. When comparing the cultivars within the treatments, the micronutrients application had the highest production of averages in relation to the biostimulant application and the control (Table 3).

The leaf area statistical evaluation showed that the biostimulant application resulted in higher averages for the Catuaí Amarelo cultivar, which differed from the other cultivars, had obtained an average higher than its control (Table 3). In results obtained by Medina et al. (2016) the use of Fitomas-E biostimulant applied at planting and after 150 days of planting in arabica coffee promoted increase to leaf area, when compared to the control. Scalon et al. (2009) also observed increased leaf area of $C$. adamantium seedlings with the use of biostimulant, however, Canesin et al (2012) warn that the use of high doses of biostimulant can inhibit metabolic processes. Thus, the general action of the plant regulators presents on the biostimulant, acting on the cellular division (PIERAZAN; SCALON; PEREIRA, 2012) and gibberellic acid acting on the leaves (LAVAGNINI et al., 2014) may have contributed to the increase of leaf area.

Comparing the treatments within the cultivars, the highest leaf area average was produced by the control, in relation to the other treatments, and the biostimulant presented the lowest average value. The Catuaí Amarelo cultivar presented the best performance of leaf area production, differing from the other cultivars in all treatments. Catuaí Vermelho 99 cultivar showed the lowest averages among the treatments differing from the other cultivars, except for Topázio cultivar within the biostimulant treatment (Table 3).

Catuaí Amarelo cultivar presented greater leaf area, whereas the Catuaí Vermelho 99 cultivar was the one that presented smaller leaf area. 
TABLE 3 - Evaluation of shoot dry mass, root dry mass, and leaf area for arabica coffee cultivars submitted to biostimulant and micronutrient application, Chapadão do Sul - MS, 2015.

\begin{tabular}{|c|c|c|c|c|c|}
\hline \multicolumn{6}{|c|}{ Cultivars } \\
\hline & Topázio & Catuaí Vermelho 99 & Catiguá & Catuaí Amarelo & Catuaí Vermelho 144 \\
\hline TRE & \multicolumn{5}{|c|}{ Evaluation of shoot dry mass (g) } \\
\hline CONT & $1.29 \mathrm{aC}$ & $0.84 \mathrm{bE}$ & $1.17 \mathrm{cD}$ & $1.59 \mathrm{bA}$ & $1.44 \mathrm{bB}$ \\
\hline $\mathrm{BIO}$ & $0.89 \mathrm{cE}$ & $0.97 \mathrm{aD}$ & $1.29 \mathrm{bB}$ & $1.69 \mathrm{aA}$ & $1.22 \mathrm{cC}$ \\
\hline $\mathrm{Co}+\mathrm{Mo}$ & $1.05 \mathrm{bC}$ & $0.59 \mathrm{cD}$ & $1.37 \mathrm{aB}$ & $1.62 \mathrm{bA}$ & $1.62 \mathrm{aA}$ \\
\hline \multicolumn{2}{|c|}{$\mathrm{CV}(\%)=2.78$} & \multicolumn{2}{|c|}{ DMS TRE $=0.07$} & \multicolumn{2}{|c|}{ DMS Cultivars $=0.06$} \\
\hline \multicolumn{6}{|c|}{ Root dry mass (g) } \\
\hline CONT & $0.54 \mathrm{aB}$ & $0.38 \mathrm{bC}$ & $0.53 \mathrm{bB}$ & $0.69 \mathrm{bA}$ & $0.63 \mathrm{bA}$ \\
\hline $\mathrm{BIO}$ & $0.49 \mathrm{abC}$ & $0.45 \mathrm{aC}$ & $0.58 \mathrm{abB}$ & $0.64 \mathrm{cAB}$ & $0.64 \mathrm{bA}$ \\
\hline $\mathrm{Co}+\mathrm{Mo}$ & $0.48 \mathrm{bC}$ & $0.30 \mathrm{cD}$ & $0.59 \mathrm{aB}$ & $0.76 \mathrm{aA}$ & $0.76 \mathrm{aA}$ \\
\hline \multicolumn{2}{|c|}{$\mathrm{CV}(\%)=5.30$} & \multicolumn{2}{|c|}{$\mathrm{DMS} \mathrm{TRE}=0.06$} & \multicolumn{2}{|c|}{ DMS Cultivars $=0.05$} \\
\hline \multicolumn{6}{|c|}{ Leaf area $\left(\mathrm{cm}^{2}\right)$} \\
\hline CONT & $17.10 \mathrm{aC}$ & $15.39 \mathrm{aD}$ & $16.95 \mathrm{aC}$ & $18.58 \mathrm{cA}$ & $17.94 \mathrm{aB}$ \\
\hline $\mathrm{BIO}$ & $15.29 \mathrm{cC}$ & $15.41 \mathrm{aC}$ & $17.16 \mathrm{aB}$ & $19.55 \mathrm{aA}$ & $17.09 \mathrm{bB}$ \\
\hline $\mathrm{Co}+\mathrm{Mo}$ & $16.02 \mathrm{bD}$ & $14.52 \mathrm{bE}$ & $17.14 \mathrm{aC}$ & $18.88 \mathrm{bA}$ & $18.22 \mathrm{aB}$ \\
\hline \multicolumn{2}{|c|}{$\mathrm{CV}(\%)=0.28$} & \multicolumn{2}{|c|}{ DMS TRE $=0.33$} & \multicolumn{2}{|c|}{ DMS Cultivars $=0.97$} \\
\hline
\end{tabular}

Averages followed by the same upper case in the line and the same lowercase in the column, do not differ each other by Tukey test $(5 \%)$. TRE $=$ treatment $\mathrm{CONT}=$ control; $\mathrm{BIO}=$ biostimulant $\mathrm{Co}+\mathrm{Mo}=$ cobalt + molybdenum; $\mathrm{CV}$ $(\%)=$ coefficient of variation; DMS = significant minimal difference.

There was no statistically difference of the treatments in the Catiguá cultivar, for Topázio and Catuaí Vermelho 99 cultivars the control did not differ from the biostimulant treatment, differing only from the micronutrient application. The biostimulant application for Catuaí Amarelo cultivar was the one that presented higher average value, differing from the control and the treatment of micronutrient. The micronutrient treatment was the best for Catuaí Vermelho 144 cultivar do not differ from the control (Table 3 ).

The height/diameter ratio (HDR), height/ shoot dry mass ratio (HSDMR), shoot/root dry mass ratio (SRDMR), Dickson Quality Index (DQI) showed significant responses to the different cultivars as a function of the biostimulant and micronutrient application (Table 4).

When the biostimulant was applied to height/diameter ratio (HDR), the cultivar that obtained the highest average was Catuaí Amarelo, differing from the other cultivars and being larger than the average of the control (Table 4).
Using micronutrients, the Catiguá cultivar obtained the highest average, but there was no statistical differentiation of Catuaí Amarelo and Catuaí Vermelho 144 cultivars. The Catiguá and Catuaí Vermelho 99 cultivars obtained higher averages than those of their control. The Topázio cultivar had the lowest average, but it was not statistically different from Catuaí Vermelho 99 cultivar (Table 4). The values from height/ diameter ratio (HDR) varied from 2.48 to 3.98 , different from the recommendation by Marana et al. (2008), wherein reasonable values for arabica coffee are from 3.5 to 4.0. These authors argue that values greater than 4.0 indicate excessive seedlings development at height, and smaller values indicate less development.

For the height/shoot dry mass ratio (HSDMR), with the biostimulant application, it was observed that Topázio cultivar obtained the highest average, differing from the other cultivars and being superior to control. The Catuaí Amarelo cultivar presented the lowest average, but there was no difference with the Catiguá and Catuaí Vermelho 144 cultivars. 
TABLE 4 - Average values for shoot height/collar diameter ratio, height/shoot dry mass ratio, shoot/root dry mass ratio and Dickson quality index for cultivars of arabica coffee submitted to biostimulant and micronutrient application, Chapadão do Sul, MS, 2015.

\begin{tabular}{|c|c|c|c|c|c|}
\hline \multicolumn{6}{|c|}{ Cultivars } \\
\hline & Topázio & Catuaí Vermelho 99 & Catiguá & Catuaí Amarelo & Catuaí Vermelho 144 \\
\hline TRE & \multicolumn{5}{|c|}{ Height/collar diameter ratio } \\
\hline CONT & $2.69 \mathrm{aBC}$ & $2.66 \mathrm{aC}$ & $2.86 \mathrm{bAB}$ & $3.00 \mathrm{bA}$ & $2.82 \mathrm{aABC}$ \\
\hline $\mathrm{BIO}$ & $2.48 \mathrm{bD}$ & $2.66 \mathrm{aCD}$ & $3.04 \mathrm{aB}$ & $3.98 \mathrm{aA}$ & $2.80 \mathrm{aC}$ \\
\hline $\mathrm{Co}+\mathrm{Mo}$ & $2.55 \mathrm{abC}$ & $2.70 \mathrm{aBC}$ & $3.00 \mathrm{abA}$ & $2.94 \mathrm{bA}$ & $2.87 \mathrm{aAB}$ \\
\hline \multicolumn{2}{|c|}{$\mathrm{CV}(\%)=3.25$} & \multicolumn{2}{|c|}{ DMS TRE $=0.19$} & \multicolumn{2}{|c|}{ DMS Cultivars $=0.16$} \\
\hline & \multicolumn{5}{|c|}{ Height/shoot dry mass ratio } \\
\hline CONT & $5.19 \mathrm{cC}$ & $6.75 \mathrm{bA}$ & $6.00 \mathrm{aB}$ & $4.89 \mathrm{abC}$ & $5.00 \mathrm{bC}$ \\
\hline $\mathrm{BIO}$ & $6.63 \mathrm{aA}$ & $5.85 \mathrm{cB}$ & $5.55 \mathrm{bBC}$ & $5.25 \mathrm{aC}$ & $5.54 \mathrm{aBC}$ \\
\hline $\mathrm{Co}+\mathrm{Mo}$ & $6.05 \mathrm{bB}$ & $9.68 \mathrm{aA}$ & $5.16 \mathrm{bC}$ & $4.79 \mathrm{bCD}$ & $4.58 \mathrm{bD}$ \\
\hline \multicolumn{2}{|c|}{$\mathrm{CV}(\%)=4.22$} & \multicolumn{2}{|c|}{ DMS TRE $=0.49$} & \multicolumn{2}{|c|}{ DMS Cultivars $=0.42$} \\
\hline & \multicolumn{5}{|c|}{ Shoot/root dry mass ratio } \\
\hline CONT & $2.41 \mathrm{aA}$ & $2.22 \mathrm{aA}$ & $2.23 \mathrm{aA}$ & $2.30 \mathrm{bA}$ & $2.28 \mathrm{aA}$ \\
\hline $\mathrm{BIO}$ & $1.84 \mathrm{bC}$ & $2.18 \mathrm{aB}$ & $2.25 \mathrm{aB}$ & $2.67 \mathrm{aA}$ & $1.90 \mathrm{bC}$ \\
\hline $\mathrm{Co}+\mathrm{Mo}$ & $2.22 \mathrm{aA}$ & $1.95 \mathrm{bB}$ & $2.32 \mathrm{aA}$ & $2.13 \mathrm{bAB}$ & $2.13 \mathrm{aAB}$ \\
\hline \multicolumn{2}{|c|}{$\mathrm{CV}(\%)=5.89$} & \multicolumn{2}{|c|}{ DMS TRE $=0.26$} & \multicolumn{2}{|c|}{ DMS Cultivars $=0.22$} \\
\hline & \multicolumn{5}{|c|}{ Dickson quality index } \\
\hline CONT & $0.36 \mathrm{aB}$ & $0.25 \mathrm{bC}$ & $0.33 \mathrm{bB}$ & $0.43 \mathrm{bA}$ & $0.41 \mathrm{bA}$ \\
\hline $\mathrm{BIO}$ & $0.32 \mathrm{bC}$ & $0.29 \mathrm{aC}$ & $0.35 \mathrm{abB}$ & $0.35 \mathrm{cB}$ & $0.39 \mathrm{bA}$ \\
\hline $\mathrm{Co}+\mathrm{Mo}$ & $0.32 \mathrm{bC}$ & $0.19 \mathrm{cD}$ & $0.37 \mathrm{aB}$ & $0.47 \mathrm{aA}$ & $0.48 \mathrm{aA}$ \\
\hline \multicolumn{2}{|c|}{$\mathrm{CV}(\%)=4.30$} & \multicolumn{2}{|c|}{ DMS TRE $=0.03$} & \multicolumn{2}{|c|}{ DMS Cultivars $=0.03$} \\
\hline
\end{tabular}

Averages followed by the same upper case in the line and the same lowercase in the column, do not differ from each other by the Tukey test (5\%). TRE $=$ treatment; $\mathrm{CONT}=$ control; $\mathrm{BIO}=$ biostimulant; $\mathrm{Co}+\mathrm{Mo}=$ cobalt and molybdenum; CV (\%) = coefficient of variation; DMS = significant minimal difference.

The Catuaí Vermelho 99 cultivar presented the highest average in relation to the others with the micronutrients application. Catuaí Vermelho 144 showed the lowest average, but did not differ statistically from Catuaí Amarelo cultivar (Table 4). According to Gomes and Paiva (2011) as lower this index, more lignified will be the seedling and greater its survival capacity in the field. The biostimulant application obtained higher performance for the Topázio and Catuaí Vermelho 144 cultivars differing from the other treatments, whereas for the Catuaí Amarelo cultivar it also presented higher performance, but did not differ from the control. The best cultivar for the control was Catuaí Vermelho 99, differing from the other cultivars. In the treatment of $\mathrm{Co}+\mathrm{Mo}$ the cultivar with the best response to treatment was Catuaí Vermelho 99, differing statistically from the other cultivars.
The biostimulant application in shoot/root dry mass ratio (SRDMR) the Catuaí Amarelo cultivar obtained the highest average, differing from all other cultivars. Topázio and Catuaí Vermelho 144 cultivars presented the smallest average, do not differ from each other. The Catiguá cultivar obtained the highest average with the micronutrients application, but there was no difference with Topázio, Catuaí Amarelo and Catuaí Vermelho 144 cultivars. From the cultivars cited, only Catiguá obtained higher average than control. Catuaí Vermelho 99 cultivar obtained the lowest average in relation to the others (Table 4).

For shoot/root dry mass ratio (SRDMR), Marana et al. (2008) reached the value 4.7 as the best ratio. The same authors affirm that values smaller than 4.7 suggest that the seedling did not 
have a good shoot increment, and values over 7.0 the development of the root system apparently was insufficient. According to Lima et al. (2008), this imbalance can damage the seedlings adaptation after planting in a definitive location, due to the fact that the root system is small, making it difficult to absorb water and support seedling in the soil.

Regarding to the Dickson Quality Index (DQI), Marana et al. (2008) report that quality seedlings are those with a minimum value 0.21 . When the biostimulant was used, Catuaí Vermelho 144 cultivar had the highest DQI, but this index was lower than the control, proving that Trazzy, Caldeira e Colombi (2010) concluded in their work that Dickson Quality Index is variable according to species, management of seedlings in the nursery, substrate proportion type, container volume and age at which seedling was evaluated. Topázio and Catuaí Vermelho 99 obtained the lowest DQI and did not differ statistically.

When applied the micronutrient, Catuaí Vermelho 144 cultivar was that obtained the highest quality index that did not differ statistically from Catuaí Amarelo. Both had higher quality index than their control (Table 4). Gomes and Paiva (2011) affirm that when higher the index value, better the seedlings standard quality.

\section{CONCLUSIONS}

The application of biostimulant and micronutrient did not present uniformity among the evaluated parameters for the different cultivars, and the cultivar Catuaí Amarelo presented better performance in the parameters evaluated with the application of biostimulant, indicating that the application of Stimulate ${ }^{\circledR}$ is an alternative with potential for the use of seedlings of this cultivar. However, there was a negative effect on the application of biostimulant and micronutrient to Topázio cultivar.

\section{REFERENCES}

ALVARENGA, S. M. et al. Marcadores moleculares derivados de sequências expressas do genoma café potencialmente envolvidas na resistência à ferrugem. Pesquisa Agropecuária Brasileira, Brasília, v. 46, n. 8, p. 890-898, Aug. 2011.

ALVES, J. D.; GUIMARÃES, R. J. Sintomas de desordens fisiológicas em cafeeiro. In: GUIMARÃES, R. J.; MENDES, A. N. G.; BALIZA, D. P. (Ed.). Semiologia do cafeeiro: sintomas de desordens nutricionais, fitossanitárias e fisiológicas. Lavras: UFLA, 2010. p. 169-215.
BINSFELD, J. A. et al. Uso de bioativador, bioestimulante e complexo de nutrientes em sementes de soja. Pesquisa Agropecuária Tropical, Goiás, v. 44, n. 1, p. 88-94, Jan/Mar. 2014.

BONOMO, R. et al. Produtividade de cafeeiros arábica irrigados no Cerrado Goiano. Pesquisa Agropecuária Tropical, Goiás, v. 38, n. 4, p. 233-240, Oct/Dec. 2008.

CANESIN, Â. et al. Bioestimulante no vigor de sementes e plântulas de faveiro (Dimorphandra mollis Benth.). Cerne, Lavras, v. 18, n. 2, p. 309-315, Apr/ June. 2012.

CONAB, Companhia Nacional de Abastecimento. Acompanhamento de safra brasileira de café, Safra 2017. Conab, v. 4, n. 2, p. 1-104, May. 2017.

CUNHA, F. F.; MAGALHÃES, F. F.; CASTRO, M. A. Métodos para estimativa da evapotranspiração de referência para Chapadão do Sul - MS. Engenharia na agricultura, Viçosa, v. 21, n. 2, p. 159-172, Mar. 2013.

DICKSON, A.; LEAF, A. L.; HOSNER, J. F. Quality appraisal of white spruce and white pine seedling stock in nurseries. Forest Chronicle, Ontário, v. 36, n. 1, p. 10-13, 1960.

ESQUIROL, C. F. R. et al. FitoMas-E: una alternativa para el enraizamiento in vitro de cultivares de caña de azúcar. Biotecnología Vegetal, Cuba, v. 16, n. 4, p. 239-244, Oct/Dec. 2016.

FAROOQ, M.; WAHID, A. Y.; SIDDIQUE, K. H. M. Micronutrient application through seed treatments. Journal of Soil Scienceand Plant Nutrition, Temuco, v. 12, n. 1, p. 125-142, Jan/Mar. 2012.

FERREIRA, D. F. SISVAR: um programa para análises e ensino de estatística. Revista Symposium, Lavras, v. 6, n. 2, p. 36-41, July. 2008.

GOMES, J. M.; PAIVA, H. N. DE. Viveiros Florestais: propagação sexuada. 1. ed. Viçosa: UFV, 2011. 116 p.

KISSMANN, C. et al. Biorregulador e précondicionamento osmótico na germinação de sementes e no crescimento inicial da muda de carobinha (Jacaranda decurrens subsp. symmetrifoliolata Farias \& Proença) -Bignoniaceae. Revista Brasileira de Plantas Medicinais, Botucatu, v. 13, n. 1, p. 58-67, Jan/Mar. 2011. 
LAVAGNINI, C. G. et al. Fisiologia vegetal-hormônio giberelina. Revista Científica Eletrônica de Agronomia, Garças, v. 25, n. 1, p. 48-52, July. 2014.

LIMA, J. D. et al. Efeitos da luminosidade no crescimento de mudas de Caesalpinia ferrea Mart. ex Tul. (Leguminosae, Caesalpinoideae). Acta Amazonica, Manaus, v. 38, n. 1, p. 5-10, Jan/Mar. 2008.

MAGUIRE, J. D. Speed of germination aid in selection and evaluation for seedling emergence and vigor. Crop Science, Madison, v. 2, n. 2, p. 176-77, Mar. 1962.

MALAVOLTA, E. Manual de nutrição mineral de plantas. 2. ed. São Paulo: Agronômica Ceres, 2006. $638 \mathrm{p}$.

MARANA, J. P. et al. Índices de qualidade e crescimento de mudas de café produzidas em tubetes. Ciência Rural, Santa Maria, v. 38, n. 1, p. 39-45, Jan/ Fev. 2008.

MEDINA, A. D. et al. Influencia del bioestimulante FitoMas-E sobre la producción de posturas de cafeto (Coffea arabica L.). Centro Agrícola, Santa Clara, v. 43, n. 4, p. 29-35, Oct/Dec. 2016.

PERDONÁ, M. J.; SORATTO, R. P.; ESPERANCINI, M. S. T. Desempenho produtivo e econômico do consórcio de cafeeiro arábica e nogueira-macadâmia. Pesquisa Agropecuária Brasileira, Brasília, v. 50, n. 1, p. 12-23, Jan. 2015.

PIERAZAN, L.; SCALON, S. P. Q.; PEREIRA, Z. V. Emergência de plântulas e crescimento de mudas de jatobá com uso de bioestimulante e sombreamento. Cerne, Lavras, v. 18, n. 1, p. 127-133, Jan/Mar. 2012.
PRADO NETO, M. et al. Germinação de sementes de jenipapeiro submetidas à pré-embebição em regulador e estimulante vegetal. Ciência e Agrotecnologia, Lavras, v. 31, n. 3, p. 693-698, May/June. 2007.

SCALON, S. P. Q. et al. Germinação de sementes e crescimento inicial de mudas de Campomanesia adamantium Camb.: Efeito da lavagem, temperatura e de bioestimulantes. Revista Brasileira de Sementes, Londrina, v. 31, n. 2, p. 96-103, Apr/June. 2009.

SFREDO, G. J.; OLIVEIRA, M. C. N. DE. Soja: molibdênio e cobalto. 21. Ed. Paraná: Documentos Embrapa Soja, 2010. 36 p.

SILVA, L. C. F. et al. Agricultura bioestimulada. Cultivar Grandes Culturas, São Carlos, v. 14, n. 162, p. 34-35, Nov. 2012.

SILVA, C. A.; TEODORO, R. E. F.; MELO, B. Produtividade e rendimento do cafeeiro submetido a lâminas de irrigação. Pesquisa Agropecuária Brasileira, Brasília, v. 43, n. 3, p. 387-394, Mar. 2008.

TAIZ, L. et al. (eds.). Fisiologia e desenvolvimento vegetal. 6 ed. Porto Alegre: Artmed, 2017. 858 p.

TECCHIO, M. A. et al. Stimulate no desenvolvimento de mudas de Kunquat 'nagami'. Irriga, Botucatu, v. 1, n. 1, p. 97-106, Jan/Apr. 2015.

TRAZZY, P. A.; CALDEIRA, M. V. W.; COLOMBI, R. Avaliação de mudas de Tecoma stans utilizando biossólido e resíduo orgânico. Revista de Agricultura, Piracicaba, v. 85, n. 1, p. 218-226, 2010.

WEISANY, W.; RAEI, Y.; ALLAHVERDIPOOR, K. H. Role of some of mineral nutriens in biological nitrogen fixation. Bulletin of Environment, Pharmacology and life sciences, India, v. 2, n. 4, p. 77-84, Mar. 2013. 